\title{
Traditional Values and Human Rights of LGBT under the Contemporary International Law
}

Nataliya S. Semenova

Ekaterina V. Kiseleva

Marianna V. Ilyashevich

Ekaterina S. Alisievich

People's Friendship University of Russia, 117198, Moscow Miklukho-Maklaya str. 6, Russian Federation

\author{
Doi:10.5901/mjss.2015.v6n5p305
}

\section{Abstract}

Respect for human rights is a fundamental principle of the modern international law, enshrined in the Charter of the United Nations Organization. Human rights form one of the three key pillars of the UN activities. Both issues taken into the title of the present paper are at the forefront in the international debates in recent years. Both issues have the potential for strengthening or weakening the effectiveness of international cooperation in the field of human rights. The article considers the contemporary stance of the international law in respect of traditional values and human rights of lesbians, gays, bisexuals, and transgenders (LGBT), exposes the arguments of the proponents of each in an attempt to enhance the better protection of human rights worldwide. It also reveals the role of the Russian Federation in promoting the protection of traditional values, among which the primary significance belongs to the concept of a traditional family. The paper consists of introduction, literature and methodology review, the discussion part on importance of traditional values in context of the LGBT propaganda, and the part devoted to the efforts and activities undertaken by Russia that is one of the key states contesting the promotion of human rights of LGBT at the expense of traditional values' protection.

Keywords: international law, human rights, United Nations, Human Rights Council, traditional values, legal protection of traditional values, education, protection of a family, LGBT.

\section{Introduction}

Respect for human rights is a fundamental principle of the modern international law, enshrined in the Charter of the United Nations (UN) Organization. Human rights form one of the three key pillars of the UN activities. Both issues taken into the title of the present paper are at the forefront of the international debates in recent years. Both issues have the potential for strengthening or weakening the effectiveness of the international cooperation in the field of human rights.

Human rights are applicable to any person on basis of the same principles and taking into account all kind of differences that are present among human beings. However, human rights idea (I) depends on our understanding of what a human being is, understanding of normalcy and deviation. A deviation needs affirmative actions while normalcy needs only protection. Traditional values help understanding what is normal. For instance, a child differs from an adult, as it is indicated in the preamble of the Convention on the rights of a child, 1989 (Convention on the rights of the child, 1989. P. 3.), with reference to the Declaration of the Rights of the Child (Resolution 1386, 1959), "by reason of his physical and mental immaturity". It means that a 'normal' human is the one physically and mentally mature. Otherwise, a person "needs special safeguards and care" (ibid).

A disabled person, as it follows from the definition of Standard Rules on the Equalization of Opportunities for Persons with Disabilities, 1994 (Resolution A/RES/48/96, 1994), is a person with "different functional limitations" (ibid. Para. 17). Alternatively, "Persons with disabilities include those who have long-term physical, mental, intellectual or sensory impairments which in interaction with various barriers may hinder their full and effective participation in society on an equal basis with others" (Convention on the rights of persons with disabilities, 2006. P. 3). It means that a 'normal' human is a person without 'different functional' 'impairments'. Otherwise, a person needs assistive devices or adapted or specialized products, environments, programmes and services (mutatis mutandis) from definition of 'universal design' as given in art. 2 of the same Convention).

From this point of view, if we speak about human rights of LGBT we take them different from others. They are equal with 'normal humans' in everything, but the sphere of sexuality and the reproductive sphere. Reproduction of the 
humanity generally occurs through the institution of family. LGBT couples (two gay men or gay women, etc.), from biological point of view, are incapable of reproduction. In case, being a LGBT is a choice, family rights are voluntarily waived by the LGBT community. In case, being a LGBT is biologically predetermined, but a person wish to marry and start a family (and a family can be started by a man and a woman as stated in numerous treaties), and the international law protects the right.

\section{Literature Review}

In Russian international legal literature, the issues related to the protection of traditional values in the light of gender aspects received rather little attention. In this connection, one shall mention the collection of articles "Gender aspects and traditional values in the public international law," published in 2015. This collection contains a number of articles on various aspects of the problem in question. Separate publications on the subject shall be mentioned as well, for example, Kartashkin V.A. Universalization of human rights and traditional values of mankind, 2012; Semenova N.S. Preservation of traditional values and international obligations of the Russian Federation under the right to education, 2014; Ponkin I.V. "Development of family values in education system"), 2004.

In contrast, in the foreign international legal literature offers a substantial number of publications devoted to the protection of the rights of LGBT. For example, David E. Newton Gay and Lesbian Rights: A Reference Handbook, 2009; Rose K. Diverse Communities: The Evolution of Lesbian and Gay Politics in Ireland, 1994; Smith M. Political Institutions and Lesbian and Gay Rights in the United States and Canada, 2008; Clapham A. Homosexuality, a European Community Issue: Essays on Lesbian and Gay Rights in European Law and Policy, 1993; Gessen M. The Rights of Lesbians and Gay Men in the Russian Federation: An International Gay and Lesbian Human Rights Commission Report, 1994; Wintemute R., Mads Tønnesson Andenæs Legal Recognition of Same-sex Partnerships: A Study of National, European and International Law, 2001; Indrani Sen Gupta Human Rights of Minority and Women's: Human rights and sexual minorities, 2005; Dorett Funcke, Petra Thorn Die gleichgeschlechtliche Familie mit Kindern: Interdisziplinaere Beitraege zu einer neuen Lebensform, 2010; Toner H. Partnership Rights, Free Movement, and EU Law, 2004; Mooney Cotter A.-M. Ask No Questions: An International Legal Analysis on Sexual Orientation Discrimination, 2010; etc.

\section{Methodology}

During the preparation of present paper, the authors used well-known common scientific and special methods of inquiry. The paragraphs 5.1 and 5.2, in the first place, use the method of analysis, as well as the principle of objectivity, which allowed considering the problem of relationship between the concepts of traditional values and the rights of LGBT, including some aspects of their intersection, from the opposite points of view. Among the special methods of inquiry, especially paragraph 5.2 widely uses the comparative method of inquiry aiming to identify the degree of generality between different groups of sources with the view to strengthen the elaborated line of argument. In addition, especially the paragraph 5.3 use the historical method, which made possible to conduct the study of the social phenomena and concepts (such as traditional values, family, etc.) in their development and change, as well as in association with each other. Moreover, this method has allowed identifying and evaluating the origin and meaning of traditional values' concept at the present day.

\section{Results}

It is possible to submit four main theses because of the discussion presented in further part of the paper.

1. Traditional values and human rights of LGBT are from different orders, although they both are at the heart of understanding human rights generally albeit giving an opposite understanding of human rights ideal and, thus, mutually excluding each other largely.

2. The issues are of similar level of the Human Rights Council (HRC) involvement; however, the campaign around the two issues is not comparable. LGBT rights are lobbied fiercely while traditional values are promoted quite moderately, if not modestly.

3. The argumentation is very much alike for the two issues. Both cite the Universal Declaration of Human Rights, 1948, (UDHR) as one of their core arguments, however the LGBT activists rely strongly only on the first sentence thereof while advocates of traditional values found their views on the comprehensive text of the relevant para. 1 Art. 1 UDHR. The two ideas (of traditional values and LGBT rights) differ substantially in objectiveness with LGBT adherents using a one-sided approach and totalitarian language. 
4. Nowadays, the Russian Federation plays a key role in the sphere of protection and strengthening of traditional values at the universal level of international cooperation. 'Traditional values' is an accepted concept, being used in different international legal instruments and, first of all, in documents of UN human rights bodies. It is completely wrong to qualify the traditional values as relic of the past, reckoning among them malpractices (such as domestic violence or genital mutilation). The traditional values, on contrary, represent the province of all humanity and are to be duly respected and promoted by international community.

\section{Discussion}

\subsection{Universal involvement into the concepts of "traditional values" and "human rights of LGBT"}

If we take into account the highest level possible in tackling human rights issues, we see that not a single universal treaty contains explicit reference to either traditional values or LGBT rights (used here instead of 'sexual orientation' and 'gender identity'). In the agenda of the HRC, the two issues emerged nearly simultaneously and started parallel development.

The first ever resolution about traditional values was adopted by the HRC on October 2, 2009 - "Promoting human rights and fundamental freedoms through a better understanding of traditional values of humankind" (Resolution A/HRC/RES/12/21, 2009). In its resolution 16/3 dated March 24, 2011 "Promoting human rights and fundamental freedoms through a better understanding of traditional values of humankind" (Resolution A/HRC/RES/16/3, 2011), the HRC "affirmed that dignity, freedom and responsibility are traditional values, shared by all humanity and embodied in universal rights instruments, recognized that the better understanding and appreciation of these values contribute to promoting and protecting human rights and fundamental freedoms, and requested the Advisory Committee to prepare a study on how a better understanding and appreciation of traditional values of dignity, freedom and responsibility could contribute to the promotion and protection of human rights". The preliminary study was taken into account by the HRC resolution "Promoting human rights and fundamental freedoms through a better understanding of traditional values of humankind: best practices" (Resolution A/HRC/RES/21/327, 2012) on September 27, 2012, and final study was submitted on December 6, 2012 (Resolution A/HRC/22/71, 2012).

LGBT issues were raised for the first time in the Resolution of the HRC "Human rights, sexual orientation and gender identity" (Resolution A/HRC/17/19, 2011). This resolution requested "the United Nations High Commissioner for Human Rights to commission a study, to be finalized by December 2011, documenting discriminatory laws and practices and acts of violence against individuals based on their sexual orientation and gender identity, in all regions of the world, and how international human rights law can be used to end violence and related human rights violations based on sexual orientation and gender identity" (ibid. Para. 1). The study was submitted on November 17, 2011 (Discriminatory laws and practices and acts of violence against individuals based on their sexual orientation and gender identity. A/HRC/19/41, 2011), and acknowledged in the second resolution on the issue ever - "Human rights, sexual orientation and gender identity" (Resolution 27/32, see A/69/53/Add.1, 2014. P. 105-106).

\subsection{Brief comparison of argumentation of two concepts.}

There are two resolutions by the HRC and a study on each side. That makes the comparison short and clear.

The resolutions and studies were issued in the same period of time (2011-2014) and the resolutions were adopted with a similar majority of the Council.

\begin{tabular}{|c|c|c|c|}
\hline & In favour & Against & Abstention \\
\hline $\begin{array}{l}\text { Promoting human rights and fundamental freedoms through a better understanding of traditional values of humankind. } \\
\text { A/HRC/RES/16/3. }\end{array}$ & 24 & 14 & 7 \\
\hline Human rights, sexual orientation and gender identity. A/HRC/17/19. & 23 & 19 & 3 \\
\hline $\begin{array}{l}\text { Promoting human rights and fundamental freedoms through a better understanding of traditional values of humankind: } \\
\text { best practices. A/HRC/RES/21/3. }\end{array}$ & 25 & 15 & 7 \\
\hline Human rights, sexual orientation and gender identity. A/HRC/27/32. (One delegation did not participate in voting). & 25 & 14 & 7 \\
\hline
\end{tabular}

Source: prepared by E. Kiseleva.

The volume of the documents is comparable, as well. They contain 2-3 pages. 


\begin{tabular}{|c|c|c|}
\hline & No. of para. in preamble & No. of para. in the substantive part \\
\hline $\begin{array}{l}\text { Promoting human rights and fundamental freedoms through a better understanding of } \\
\text { traditional values of humankind. A/HRC/RES/16/3. }\end{array}$ & 7 & 7 \\
\hline Human rights, sexual orientation and gender identity. A/HRC/17/19. & 4 & 4 \\
\hline $\begin{array}{l}\text { Promoting human rights and fundamental freedoms through a better understanding of } \\
\text { traditional values of humankind: best practices. A/HRC/RES/21/3. }\end{array}$ & 9 & 7 \\
\hline $\begin{array}{l}\text { Human rights, sexual orientation and gender identity. A/HRC/27/32. (One delegation } \\
\text { did not participate in voting). }\end{array}$ & 8 & 3 \\
\hline
\end{tabular}

Source: prepared by E. Kiseleva.

Although the language seems also very much alike, the details show the differences in basis for the respective contentions and objectiveness of the approach.

Both resolutions on the traditional values start with the reference to "the purposes and principles set forth in the Charter of the United Nations" (para. 1 of both Resolutions preambles), and reiterate its guidance with "the Charter, other instruments relating to human rights, and international law" (para. 3 and 4 of the respective Resolutions preambles). No such reference can be found in the Resolutions on LGBT. The latter point only to "the universality, interdependence, indivisibility and interrelatedness of human rights as enshrined in the UDHR and consequently elaborated in other human rights instruments, such as the International Covenant on Economic, Social and Cultural Rights, the International Covenant on Civil and Political Rights and other relevant core human rights instruments" (para. 1 of both Resolutions preambles, emphasis added). The difference is that the mentioned character of human rights is on the one hand, but the reference to the international law is on the other. The former is in common between all four documents. From the point of the international law, it is commonplace that the UDHR standards were further elaborated in the two Covenants. However, it is not the same as to state that the treaties can substantiate the claim for the specific issue of either traditional values or LGBT rights. No universal treaty can be used for lobbying 'sexual orientation' and 'gender identity', and that is the reality for the authors of the Resolutions. They can only cite themselves and broadly "all relevant Human Rights Council and General Assembly resolutions on combating all forms of discrimination and violence exercised due to discrimination of any kind" (para. 5 of the latest Resolution preamble) and study "how international human rights law can be used to end violence and related human rights violations based on sexual orientation and gender identity" (para.1 of Resolution 17/19), i.e. mix and confuse the problems of 'violence' that is, in a sense the word is used here, inadmissible to literary every person, with desire to spread 'sexual orientation' and 'gender identity' as allegedly inappropriate criteria for differential treatment.

All the four documents refer to the UDHR, Vienna Declaration and Programme of Action. All the documents repeat the universality, interdependence, indivisibility, and interrelatedness of human rights, necessity to promote and respect all human rights in a fair and equal manner, etc.

The two pairs of documents differ in their level of objectiveness, openness to a critique. In the documents on traditional values there is the sincere awareness of possible misuse of the concept and warning against it, e.g. "while the significance of national and regional particularities and various historical, cultural and religious backgrounds must be borne in mind, all States, regardless of their political, economic and cultural systems, have the duty to promote and protect all human rights and fundamental freedoms" (para. 3 and 5 of the respective Resolutions preambles), "stressing that traditions shall not be invoked to justify harmful practices violating universal human rights norms and standards" (para. 6 and 7 of the respective Resolutions preambles). There is nothing similar in the LGBT resolutions. Authors thereof remain silent about the destructive effect of their concepts on the individuals, families and societies of the world.

It is also illustrative, how the HRC formulates its requests for studies in the two cases. Resolution 16/3 on traditional values "welcomes the holding on 4 October 2010 of a workshop for an exchange of views on how a better understanding of traditional values of humankind..." (para. 1); "also welcomes the report of the Office of the United Nations High Commissioner for Human Rights containing the summary of the discussions held at the said workshop" (para. 2); "requests the Human Rights Council Advisory Committee to prepare a study on how a better understanding and appreciation of traditional values of dignity, freedom and responsibility can contribute to the promotion and protection of human rights, and to present that study to the Council before its twenty-first session" (para.6). Resolution 21/3 "requests the Office of the United Nations High Commissioner for Human Rights to collect information from States Members of the United Nations and other relevant stakeholders on best practices in the application of traditional values while promoting and protecting human rights and upholding human dignity, and to submit a summary thereon to the Human Rights Council before its twenty-fourth session" (para. 6). Balanced approach, effort to cover all details and listen to all voices are worded in the Resolutions. 
On the other hand, Resolution 17/19 on LGBT "1. Requests the United Nations High Commissioner for Human Rights to commission a study, to be finalized by December 2011, documenting discriminatory laws and practices and acts of violence against individuals based on their sexual orientation and gender identity, in all regions of the world, and how international human rights law can be used to end violence and related human rights violations based on sexual orientation and gender identity; 2 . Decides to convene a panel discussion during the nineteenth session of the Human Rights Council, informed by the facts contained in the study commissioned by the High Commissioner and to have constructive, informed and transparent dialogue on the issue of discriminatory laws and practices and acts of violence against individuals based on their sexual orientation and gender identity; 3 . Also decides that the panel will also discuss the appropriate follow-up to the recommendations of the study commissioned by the High Commissioner". Therefore, the first step is to document violations (cf. to study the problem, its relevance, and root causes, etc., no cooperation with states declared). The second step is to discuss the findings (not vice versa; not ask for the information and then discuss it, but give the necessary information and then give a word to the opponents). The third step is to elaborate on mechanism taking for granted that the states agree.

It is curious that only one of the four documents concerned dared to name the issue thereof as a priority. That was the first Resolution on LGBT. Fortunately, this word disappeared from the later text.

Let us now give greater attention to the protection traditional values in Russian Federation, as one of the states, making great efforts to protect traditional values (one of which is traditional family) on universal level of international cooperation - first, in frames of UN human rights bodies' activities.

\subsection{The role of the Russian Federation in promoting traditional values}

On September 27, 2012, the UN CHR adopted on the proposal of the Russian Federation, the mentioned above Resolution 21/3 "Promoting human rights and fundamental freedoms through a better understanding of traditional values of humankind: best practices".

The reasons for Russia to propose a draft of such a resolution is related to today's revision by the countries of the Western Europe and the North America of the fundamental values of humanity, values that contain not only the unshakeable foundations of morality and ethics, but also the survival of humanity itself.

An absolute majority adopted the resolution $21 / 3$, but all the countries of the Western and the Eastern Europe, and the United States voted against it.

Justifying its position, the representative of Norway, in particular, pointed out that in the international law there is no unambiguous definition of concepts such as 'traditions' and 'values'; these concepts can be used to the detriment of human rights and, if desired, the 'traditional values' can be found in phenomena such as domestic violence and slavery. This point of view was supported by Austria, speaking on behalf of the European Union (see: Russian Ministry of Foreign Affairs site). Mentioned position seems unreasonable, because there are a number of concepts that are not enshrined in the international law in writing by virtue of the fact that they are clear to everyone and do not require any explanation.

According to Professor E.A. Lukasheva, in human rights the complementarity of law and morality develops in the reproduction and protection of universally valid (unconditional and absolute) values of a civilized human activity and communication. Aristotle wrote about such significances as about common for all, as recognized as such by all nations, even if among them there is no connection and no agreement about this ... Main role of 'common to all' values is forming a complex of social norms of increased significance aimed to meet these values. This complex is included in the human rights that have an important normative valuable significance for the legal and moral systems (Human Rights. Textbook for High Schools, 2001. P. 266-267).

In addition, the UN General Assembly in its resolutions has repeatedly pointed to the importance of "fundamental" and "common fundamental" values for international relations (United Nations Millennium Declaration, Resolution A/RES/55/2, 2000. Para. 6; World Summit Outcome Resolution A/RES/60/1, 2005. Para. 4). HRC Resolutions 12/21 and $16 / 3$ mention "traditional values of humankind" and "common set of values that belong to humankind in its entirety". These expressions have the same meaning. The concept of the "universal values" could also be added (Preliminary study on promoting human rights and fundamental freedoms through a better understanding of traditional values of humankind. A/HRC/AC/8/4, 2011. Para. 27).

The notion of the "traditional values" was mentioned in various regional documents such as the African Charter on Human Rights (Sec. 3, Art. 17). Consequently, the concept of "traditional values" is not alien to the international law, but is rather widely used in international documents. This is one more confirmation of the groundlessness of the European countries arguments against "traditional values".

This reaction of the Western countries to Resolution $21 / 3$ is understandable because of their policies on promotion 
of protection of non-traditional relationships at the national and international levels. A striking example is the legalization of gay marriage, the possibility of the adoption of children by same-sex couples, bills aimed to legalize paedophilia and incest, etc. (see: "Legalization of Incest is Widely discussed in Western Europe").

This practice is unacceptable for the Russian Federation and the states supporting concept of traditional values. The family is one of the important traditional values and the basis of any state's stability. Since the Western countries put under question the concept of the traditional family, let us consider this concept and its implications for the international legal order in terms of traditional values at the example of the Russian Federation.

The Russian Federation is a multi-ethnic and multi-confessional state. Despite the long period of Soviet militant atheism, society remains traditional. At present, Russia's policy is aimed at strengthening the state ideology based on the traditional values of the society. This is evidenced by a number of statements made by the President of the Russian Federation Vladimir Putin, as well as various government representatives (Semenova N.S., 2014. P. 60). This position is also evident in the "Framework for the cultural policy of the Russian Federation" 2014. In this regard, it is important to determine the basis of the traditional values of a society, and the meaning understood as the gender equality in their context. Correct understanding of gender equality and destruction of stereotypes is the basis for the education of future generations, and their adaptation to life in a traditional society.

As a member of the Russian Academy of Education Professor A.M. Novikov said, "the mentality of Russians was historically formed under the influence of the Orthodox Church" (Novikov A.M., 1999. P. 2-3). This means that regardless of the religion that Russian people profess (Christianity, Islam, Buddhism, Judaism, etc.); they live in a cultural space that was formed under the influence of the Orthodox Church.

One of the most important traditional values and the basis for stability of the state is a traditional family. Let us consider whether there is gender equality in the traditional Christian family. According to Orthodox doctrine, which in this respect is supported by other Russia's traditional religions (Islam, Judaism), in traditional families a husband is supposed to be a head. A number of reasons can explain this. First, it is the hierarchy established by the God: the God - husband wife - children. However, it is important to understand the nature of this hierarchy, from a Christian perspective.

A husband is a head of the family, he has greater physical strength, which he needs to protect the family and to ensure its sustenance and everything it needs. Husband is supposed to take final decisions in the family and to be responsible for them. This corresponds to a certain internal men's psychology, more rational than emotional. A woman has naturally less physical strength, but more stamina. For her it is necessary to perform the important task - procreation. Psychologically women are primarily emotional rather than rational.

These differences of male and female nature are intended to create a family as a united whole. Such a family always has equality. This equality sustains in the responsibility before the God. Husband, for example, should love his wife as himself (Epistle of St. Paul to the Ephesians, 5:33), and use his physical strength only for the protection and care of the family, and has no right to abuse it. A woman should love her husband, take care of him and bring up their children.

Thus, a traditional family is not a family if a husband beats his wife, humiliates and mocks her, but the family where both husband and wife sacrifice their interests for the sake of each other, care about each other by the capabilities that the God has given them. In other words, a subordinate position does not mean a humiliating situation. This is confirmed by the fact that each society is organized hierarchically. For example, when a person gets a job, he or she is usually in a subordinate position, but it does not mean a humiliating situation by itself.

As the family is the main unit of the society, and a society functions in a hierarchical manner, then the family cannot be an exception to this principle, because it is a part of the society.

In today's world, the role of women has changed, but male's and female's essence is unchanged. Taking over functions of another person the one takes the responsibility for their implementation as well. A wife, taking certain responsibilities of her husband, takes them off from her husband. As a result, the husband ceases to be a breadwinner and protector of the family; he loses his role as head and sole responsible person in the family. Thus, the family can be destroyed. If it is not destroyed, it may become flawed, as a body in which an organ has ceased to perform its intended function. At the same time, female nature would still require the protection by a man but it will not be possible to obtain due to the redistribution of functions in the family's organism. Conversely, manhood will subconsciously seek to restore lost functions of the head of the family. As the result, the family can become disabled.

A similar situation is with children in the family. If their place is changed, the family will suffer. Children must be in a subordinate position. It is a condition of their full development. If in the family hierarchy children are heads, the family's organism suffers greatly. It is in the family that the child absorbs the core values, the concept of good and evil, a sample of the proper and improper behaviour, the pattern of relationships between people, etc.

It is also important to note that the basis of the traditional family is the principle of respect for human dignity, which is a basic concept of the theory of human rights. The UDHR starts by the recognition of the inherent dignity and of the 
equal and inalienable rights for all members of the human family, which is the foundation of freedom, justice and peace in the world (Preamble).

According to the biblical revelation, human nature is not only created by God, but is endowed with properties in His image and likeness (Gen. 1, 26). Only on this basis can be argued that human nature has an inherent dignity.

However, despite the agreement of the theory of human rights and of divine revelation that man is endowed with dignity, its content is understood in different ways. Thus, the mentioned resolution of the UN HRC 17/19 "Human rights, sexual orientation and gender identity" of 14 July 2011 was the first step to promote "non-traditional values" at the universal level. At the same time, Resolution 17/19 recalls the provisions of Article 1 of the UDHR, according to which "all human beings are born free and equal in dignity and rights." Resolution 21/3 (mentioned at the beginning of the article) also appeals to dignity and rights.

According to Professor V.A. Kartashkin, "Dignity and freedom are principles that determine an individual's position in society and the State. They are values that underpin all the human rights enshrined in international instruments... Human rights arise from the dignity and freedom of the individual and his or her responsible behaviour in respect of society and other people" (Preliminary study on promoting human rights and fundamental freedoms through a better understanding of traditional values of humankind. A/HRC/AC/8/4, 2011. Para. 31-32).

So each person is endowed with dignity and freedom. However, the use of freedom for evil inevitably entails belittling one's own human dignity and humiliation of others. Therefore, after the recognition of dignity and freedom of every person Article 1 of the UDHR states that people "are endowed with reason and conscience and should act towards one another in a spirit of brotherhood." Conscience allows the person to judge the moral and immoral deeds, good and evil. Recognition of the rights is guaranteed by the responsibility towards one another.

There is a direct link between human dignity and morality. Immoral life is unworthy of a person, because it destroys him/her, his/her health, as well as harms others and the world around. For example, smoking destroys health of a smoker and harms the health of people around him. The same is true for unnatural relations, because the recognition of human dignity means assertion of its moral responsibility. In other words, the idea of responsibility is inherent to the concept of dignity, which is necessary for compliance with law.

Morality is based on the concepts of good and evil, and is always proceeded by the law, which is based on the idea of social justice. The social justice, for its part, is also based on the concept of good and evil in a particular society at a particular historical period. For this reason, erosion of morality always eventually leads to destruction of law.

Preserving of human dignity and growing in it are ensured by the life in accordance with moral norms that are the basis of traditional values, because these norms express the primordial and true nature of an individual.

\section{Conclusion}

According to the results of the study, the most obvious contemporary tendency is not simple protecting the rights of LGBT from discrimination in various spheres of everyday life. This also includes active promoting of this way of life in order to impose ideas of the legality of the claims for LGBT equality with traditional majority, especially in the areas of family creation, birth and upbringing of children and education. On the other hand, as opposed to this tendency, with the beginning of the XXI century, some attention has been paid to the protection of traditional values of humankind (primarily, concepts of freedom, dignity and responsibility), which generally have a great potential to promote and protect human rights and fundamental freedoms.

The important role of the Russian Federation is to promote the idea of traditional values and to take a stand against the revolutionary interpretation of existing the international law provisions, as encouraging same sex relations and replacing the traditional concept of the family as a union between a man and a woman.

In view of the previously mentioned, the international legal study on gender aspects of the protection of traditional values is challenging and scientifically significant.

Nevertheless, the present study reveals only certain aspects of the issues, which certainly implies the need for further research activities in this sphere.

This paper was prepared with the assistance of the Russian State Science Foundation based on the provided research grant "Gender aspects of international legal protection of traditional values" (No. 14-33-01040).

\section{References}

Convention on the rights of persons with disabilities. New York, 13 December 2006. UNTS, Vol. 2515.

Convention on the rights of the child. New York, 20 November 1989. UNTS, Vol. 1577. 
Declaration of the Rights of the Child. Proclaimed by the UN GA Resolution 1386(XIV) of 20 November 1959.

Discriminatory laws and practices and acts of violence against individuals based on their sexual orientation and gender identity. Report of the United Nations High Commissioner for Human Rights, 17 November 2011. A/HRC/19/41.

Gender aspects and traditional values in public international law (Gendernie aspecti i tradicionnie cennosti v svete mezdunarodnogo prava): proceedings of the Round table in frames of XII Annual international conference commemorating prof. I.P.Blischenko / ed. by A.Kh.Abashidze, N.S.Semenova, E.V.Kiseleva, E.S.Alisievich. Moscow, 2015. - 240 p.

Human rights, sexual orientation and gender identity, 14 July 2011. A/HRC/17/19.

Human rights, sexual orientation and gender identity, 26 September 2014. Resolution 27/32, see A/69/53/Add.1.

Human Rights. Textbook for High Schools / Executive Editor E.A. Lukasheva (Prava cheloveka. Uchebnik dlya vuzov / otv. red. E.A. Lukasheva). Moscow, 2001.

Legalization of Incest is Widely discussed in Western Europe (V Zapadnoy Evrope shiroko obsugdaetsya legalizatsiya intsesta). URL: http://file-rf.ru/news/13808.

Novikov A.M. Russian National Ideology (possible approach) (Natsionalnaya ideya Rossii (vozmognii podhod)). M., 1999.

Preliminary study on promoting human rights and fundamental freedoms through a better understanding of traditional values of humankind. Prepared by Professor Vladimir Kartashkin, Rapporteur of the drafting group of the Advisory Committee. 12 December 2011. Resolution A/HRC/AC/8/4. URL: http://daccess-dds-ny.un.org/doc/UNDOC/GEN/G11/173/22/PDF/G1117322. pdf?OpenElement.

Promoting human rights and fundamental freedoms through a better understanding of traditional values of humankind, 2 October 2009. A/HRC/RES/12/21.

Promoting human rights and fundamental freedoms through a better understanding of traditional values of humankind, 24 March 2011. A/HRC/RES/16/3.

Promoting human rights and fundamental freedoms through a better understanding of traditional values of humankind: best practices, 27 September 2012. A/HRC/RES/21/3.

Russian Ministry of Foreign Affairs URL: http://www.mid.ru/brp_4.nsf///FD74E649332CFF3644257A86005BCDC8.

Semenova N.S. Preservation of traditional values and international obligations of the Russian Federation under the right to education. Eurasian Law Journal, N 5 (72), 2014.

Standard Rules on the Equalization of Opportunities for Persons with Disabilities, 4 March 1994. A/RES/48/96.

Study of the Human Rights Council Advisory Committee on promoting human rights and fundamental freedoms through a better understanding of traditional values of humankind, 6 December 2012. A/HRC/22/71.

United Nations Millennium Declaration, 18 September 2000. Rsolution A/RES/55/2. URL: http://www.un.org/millennium/declaration/ares 552e.pdf.

World Summit Outcome, 24 October 2005. Resolution A/RES/60/1/. URL: http://unpan1.un.org/intradoc/groups/public/documents/un/ unpan021752.pdf. 